\title{
PENGARUH HARGA TERHADAP KEPUTUSAN PEMBELIAN ULANG AKSESORIS PAKAIAN DI TOKO MINGKA BANDUNG
}

\author{
Muhamad Priyanto, Tiris Sudrartono \\ Fakultas Ekonomi dan Bisnis, Politeknik Piksi Ganesha, Program Studi Manajemen Bisnis \\ Email: Mmmdpriyanto99@gmail.com
}

\begin{abstract}
The purpose of this research is to determine the magnitude of the influence of price on the decision to re purchase clothing accessories by using 3 dimensions of price, namely affordable or not, discounts, payment methods. The research population is all buyers who have bought at the Mingka Bandung store is 5,334 customers while the sample determined using the refence calculation of the Slovin formula is 98,15 respondents to answer question on the distributed questionnaire, then statistical tests are carried out. By using SPSS V.26. The results of the analysis of the data obtained are 41,994 > ttabel 1,660, so that the hypothesis test on the variable X Price has a positive influence on the level of repurchase interest. From the result of SPSS output obtained $R$ square of 0,881. This shows that the interest in buying back accessories at the Mingka Store Bnadung can be influenced by the price given $85.0 \%$ while the remaining $12.0 \%$ is the influence or contribution of other variables not examined in the study.
\end{abstract}

Keywords: Price, Repurchase intention, Buyer

\begin{abstract}
Abstrak
Studi ini memiliki tujuan mengetahuipengaruh dari harga atas keputusan melakukan pembelian ulang aksesoris pakaian dengan menggunakan 3 dimensi Harga yaitu terjangkau atau tidaknya harga, diskon atau potongan harga, cara pembayaran. Populasi penelitian adalah semua pembeli yang pernah membeli di toko mingka bandung pada tahun 2020, dimana populasi nya berjumlah 5,334 pelanggan, sampel dengan menerapkan rumus Slovin yakni 98,15 responden pengisian kuesioner. Lalu dibantu uji statistik dengan SPSS V26. Hasil analisis data, didapatkan 41,99> $t_{\text {tabel }} 1,660$ sehingga, uji hipotesis variabel $X$, harga mempunyai pengaruh positif bagi levelminat beli ulang. Atas output SPSS, $R$ square 0,881. Hal ini menunjukan bahwa Minat Beli Ulang aksesiris di Toko Mingka Bandung mampu dipengaruhi oleh harga yang diberikan $85.0 \%$ serta $12 \%$ sisanya dipengaruhi variabel lain dari penelitian.
\end{abstract}

Kata kunci :Harga, Minat beli ulang, Pembeli.

\section{Pendahuluan}

Fashion di negara Indonesia mengalami perkembangan atas modernisasi yang menjadikan masyarakat harus selekstif untuk menetapkan pola atau gaya hidup. Gaya hidup memiliki keterkaitan erat terhadap fashion, disebabkan fashion akan mendukung penampilan individu untuk lebih menarik sehingga menjadi pusat perhatian masyarakat. Produk fashion mencakup produk yang digunakan jangka pendek dikarenakan penggunaan standar dalam jangka satu tahun. Produk fashion mencakup aksesoris, pakaian, tas, sepatu, dan sebagainya. (Zaelani, 2019)

Minat beli yaitu kecenderungan responden dalam melakukan tindakan sesudah konsumen mencapai kepuasan. 
Untuk pemasaran produk hingga penjualan, badan usaha bukan hanya melakukan penciptaan kebutuhan masyarakat, tetapi juga mempertimbangkan minat konsumen dalam mebeli. Minat tersebut tercipta apabila produk dirasa menarik, cocok, terjangkau serta mudah didapatkan (Resti, 2016)

Produk yang beragam dengan keterjangkauan harga akan memberi keuntungan bagi badan usaha perdagangan dikarenakan akan mendorong konsumen dalam mengambil tindakan membeli produk badan usaha tersebut. Menurut Kotler dan Keller (2009) keputusan dalam membeli ialah fase dimana konsumen akan membentuk niat dalam melakukan pembelian produk yang dirasa menarik serta konsumen akan melakukan modifikasi atau melakukan penundaan dipengaruhi oleh rasa resiko (Korowa et al., 2018)

Persaingan perusahaan fashion di toko bandung sangat banyak dikarenakan bandung di labeli sebagai salah satu kota fashion, maka dari itu badan usaha perlu tepat dan cepat untuk melakukan pengambilan keputusan serta mengkreatifkan ide, inovatif, kekinian agar dapat di terima oleh masyarakat luas sehingga persaingan di dunia fashion dapat bertahan. Dengan ini terdapat data penjualan aksesoris pakaian di Toko Mingka bandung sebagai berikut :

Tabel 1. Data Penjualan Toko Mingka Bandung Tahun 2020

\begin{tabular}{|c|c|c|c|}
\hline NO & BULAN & JUMLAH & \% \\
\hline 1 & Januari & $360.000,000$ & $0 \%$ \\
\hline 2 & Februari & $533.000,000$ & $48 \%$ \\
\hline 3 & Maret & 439.765 .000 & $-17 \%$ \\
\hline 4 & April & $444.908,600$ & $1,16 \%$ \\
\hline 5 & Mei & $507.890,700$ & $14 \%$ \\
\hline 6 & Juni & $486.768,000$ & $-4 \%$ \\
\hline 7 & Juli & $358.821,000$ & $-6 \%$ \\
\hline 8 & Agustus & $390.100,000$ & $3,9 \%$ \\
\hline 9 & September & $459.876,000$ & $17 \%$ \\
\hline 10 & Oktober & $483.210,000$ & $5 \%$ \\
\hline 11 & November & $560.700,000$ & $16 \%$ \\
\hline 12 & Desember & $608.430,000$ & $9 \%$ \\
\hline Sumber $:$ Data Penjualan Aksesoris Di Toko Mingka \\
Bandung Tahun 2021
\end{tabular}

Berdasarkan tabel 1 di atas menunjukan bahwa pertumbuhan di toko mingka bandung 2020 pada bulan maret mengalami penurunan sebanyak $17 \%$ dari bulan sebelumnya, lalu bulan april mengalami kenaikan sebanyak $1,16 \%$ dari sebelumnya dan pada bulan mei pun mengalami kenaikan sebanyak $14 \%$ dibanding bulan terdahulu.

Di bulan Juni terjadi penurunan dengan persentase $4 \%$ dibanding bulan Mei, di bulan Juli terjadi penurunan $6 \%$ dibanding bulan Juni, serta di bulan agustus terjadi peningkatan $3,9 \%$ dibanding bulan Juli. Dan pada bulan September mengalami 
kenaikan dengan persentase $17 \%$ dari bulan sbelumnya, dan untuk bulan oktober mengalami kenaikan dengan persentase 5\% dari bulan Septemeber, pada bulan November mengalami kenaikan dengan persentase $16 \%$ dari bulan oktober dan untuk akhir bulan desember mengalami kenaikan kembali dengan persentase 9\% dari bulan sebelumnya.

Berdasarkan penjelasan tersebut penulis menduga terdapat penjualan aksesoris mengalami naik turun di setiap bulannya yang di sebabkan oleh harga yang sangat mempengaruhi minat beli ulang di Toko Mingka Bandung.

\section{Tinjauan Pustaka}

Minat beli merupakan tahap kecenderungan responden untuk bertindak sebelum keputusan membeli benar-benar dilaksanakan. Terdapat perbedaan antara pembelian aktual dan minat pembelian. Bila pembelian aktual adalah pembelian yang benar-benar dilakukan oleh konsumen, maka minat pembelian adalah niat untuk melakukan pembelian pada kesempatan mendatang.

Adapun pembentukan terjadinya minat beli ulang antara lain :

1. kualitas

2. Keterjangkuan Harga
3. Diskon atau Potongan Harga

4. Cara pembayaran

Dengan adanya (4) faktor di atas maka dapat menciptakan ketercapaian minat beli ulang konsumen.

Keputusan pembelian merupakan lingkup dari tingkah laku pelanggan yaitu ilmu tentang kegiatan individu maupun kelompok dalam mengaplikasikan tentang persepsi suatu barang atau jasa setelah memiliki suatu produk tertentu dalam memenuhi kebutuhan dan keinginan mereka Kotler dan Amstrong (2016)

Keterjangkauan harga merupakan harga sesungguhnya dari suatu produk yang tertulis disuatu produk yang harus di bayarkan oleh pelanggan. Maksudnya adalah pelanggan cenderung melihat harga tertera dan memutuskan akan menerima nilai yang baik seperti yang di harapkan.

Menurut (Kotler dan Armstrong, 2008) harga merupakan penagihan total nilai uang atas produk yang dijual serta total nilai yang akan ditukar kepada konsumen atas manfaat yang diperoleh dari penggunaan produk itu. Penetapan harga dari badan usaha bertujuan memberikan nilai produk yang dikeluarkan. Penentuan harga dari badan usaha dengan pertimbangan penuh atas biaya selama proses produksi hingga tujuan memperoleh keuntungan maksimal. 
Adapun teori inti pembelian ini adalah teori perilaku konsumen. Teori tersebut menjabarkan bahwa perilaku konsumen merupakan fase yang dibangun dan dilaksanakan oleh individu atau kelompok orang dalam skema untuk mencukupi kebutuhan dan keinginanya Simamura (2004).

Menurut McGaghie dalam Hayati (2020), kerangka pemikiran ialah proses melakukan pengaturan dalam melakukan penyajian pertanyaan dalam penelitian dan mendorong penyelidikan atas permasalahan yang menyajikan permasalahan dan konteks penyebab peneliti melaksanakan studi tersebut. Kerangka Pemikiran studi ini ialah Harga (X) variabel independen serta Keputusan Pembelian Ulang (Y) variabel dependen.

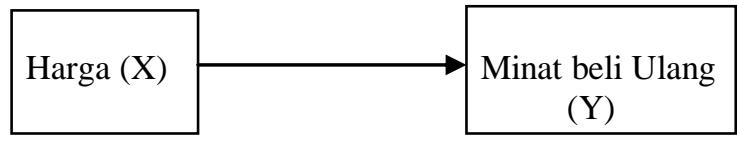

Sumber : Dibuat penulis 2021

\section{Gambar 1. Skema kerangka Pemikiran}

Berdasarkan Kerangka Pemikiran, terdapat keterkaitan variabel $\mathrm{X}$ dan $\mathrm{Y}$. harga memberikan pengaruh atas minat pembelian ulang konsumen. Badan usaha perlu mempertimbangkan kepentingan hal-hal konsumen supaya konsumen merasakan kepuasan dari ketetapan harga. Kualitas yang diberikan Toko Mingka Bandung sangat berpengaruh besar terhadap minat beli ulang konsumen di toko mingka bandung

Hipotesis yang diajukan pada penelitian ini dapat dirumuskan sebagai berikut:

$\mathrm{H}_{0}$ : Harga Mempunyai pengaruh negatif terhadap keputusan pembelian ulang

$\mathrm{H}_{1}$ : Harga berpengaruh Positif terhadap keputusan pembelian ulang

\section{Metode Penelitian}

Menurut (Sugiyono, 2013) metode penelitian yakni prosedur ilmiah dalam memperoleh informasi untuk manfaat atau tujuan khusus. Terdapat 4 aspek yang perlu dipertimbangkan, yakni prosedur ilmiah, kegunaan, cara, dan tujuan. Prosedur ilmiah yakni aktivitas penelitian yang digantungkan atas karakteristik empiris, rasional, serta sistematis.

Menurut Arikunto (2019) metode penelitian merupakan prosedur prioritas dalam penelitian demi meraih tujuan atau penentuan jawaban permasalahan yang diangkat. Sukandarrumindi dalam Thabroni (2021) metode penelitian ialah prosedur penelitian dalam meraih tujuan dan penentuan jawaban permasalahan yang diangkat. 
Penulis menerapkan metode penelitian kuantitatif deskriptif, yakni metode penelitian yang didasarkan atas aliran positivism dimana melakukan penelitian atas populasi serta sampel khusus, dengan pengumpulan data dari instrumen penelitian, serta penganalisisian kuantitatif untuk melakukan uji hipotesis (Sugiyono, 2013).

\section{Operasional variable}

Menurut Sugiyono (2013), ialah atribut objek ataupun aktivitas yang mempunyai variasi khusus dari penetapan peneliti untuk diteliti dan diambil simpulan. Operasional variabel penelitian ini yaitu dimensi yang disematkan pada suatu variabel dengan memberikan arti atau menspesifikasi kan kegiatan atau membenarkan suatu operasional yang diperlukan untuk mengukur variabel tersebut. Indikator Harga (x) yang gunakan dalam penelitian (1) Keterjangkauan Harga; (2) Diskon/Potongan Harga; (3) cara pembayaran (Kotler \& Garry : 2008). Untuk Indikator Minat beli Ulang (Y) yaitu (1) kualitas produk; (2) merek; (3) dealer; (4) jumlah pembelian; (5) waktu pembelian (Schiffman \& kanuk :2008).

\section{Populasi}

Menurut djarwanto (1994), populasi ialah total individu yag memiliki kehendak karakteristik dari peneliti. Satuan tersebut disebut unit dari analsisis baik berupa instansi, objek, atau individual. Populasi studi ini yakni pengaruh dari harga atas minat pembelian ulang aksesoris pakaian toko Mingka Bandung terdiri dari 5,334 pembeli.

\section{Sampel}

Menurut sugiyono (2013), sampel merupakan bagian dari populasi dalam penelitian. Sampel memiliki karakteristik seperti populasi dan mampu mewakili populasi pengamatan. Penelitian dengan area populasi besar akan lebih sulit dilakukan penelitian untuk pengambilan data dan memlerukan teknik dalam pengumpulan sampel.

$$
n=\frac{\mathrm{N}}{1+\mathrm{N} e^{2}}
$$

Sehingga :

$$
\begin{gathered}
\mathrm{n}=\frac{5.334}{1+\left(5.334 X 0,1^{2}\right)} \\
\mathrm{n}=\frac{5.334}{1+(5.334 X 0,01)} \\
\mathrm{n}=\frac{5.334}{1+5.334} \\
\mathrm{n}=\frac{5334}{54.34} \\
\mathrm{n}=98,15 \\
\mathrm{n}=98
\end{gathered}
$$

Jadi sampel studi ini yakni 98,15 dibulatkan 98 dari total 5.334 pelanggan 
yang membeli ulang produk di toko mingka bandung pada tahun 2020 .

\section{Teknik analisis data}

Teknik studi ini yaitu dengan pembagian kuesioner. Kuesioner ialah perangkat pernyataan dan pertanyaan tertulis terhadap responden agar dilakukan pengisian (Sugiyono, 2013). Menurut Sugiyono (2013), teknik dalam pengumpulan data ialah tahapan strategis penelitian dalam memperoleh informasi atau data. Sumber data studi ini melalui observasi.

Penulis melaksanakan pengamatan di Toko Mingka Bandung sejak 15 april hingga 20 april untuk memperoleh data data yang diperlukan. Dalam penelitian ini penulis menggunakan bantuan digital untuk melakukan kuesioner yaitu dengan Google Form yang merupakan sarana pengumpulan informasi digital atas responden dari survey atau kuis individu yang secara otomatis akan dikaitkan menuju spreadsheet dari pengisian tersebut.

\section{Hasil penelitian dan Pembahasan}

\subsection{Hasil Penelitian}

\section{Uji Validitas}

Menurut Ghozali (2017), uji validitas bertujuan melakukan pengukuran kevalidan kuesioner dengan kriteria melakukan pengungkapan dari sesuatu yang perlu diukur. Dalam mencari validitas tersebut, perlu melakukan korelasi skor dari item atas total item.

Di bawah ini output uji validitas bantuan SPSS V.26 untuk variable $\mathrm{X}$ (Harga).

\section{Tabel 2. Uji validitas X (Harga)}

\begin{tabular}{|c|c|c|c|c|}
\hline Variabel & Pernyataan & r-hitung & r-tabel & Keterangan \\
\hline \multirow{8}{*}{ Harga $(X)$} & P1 & 0,885 & 0,1671 & Valid \\
\hline & P2 & 0,922 & 0.1671 & Valid \\
\hline & P3 & 0,941 & 0,1671 & Valid \\
\hline & P4 & 0,888 & 0,1671 & Valid \\
\hline & P5 & 0,896 & 0,1671 & Valid \\
\hline & P6 & 0,847 & 0,1671 & Valid \\
\hline & P7 & 0,631 & 0,1671 & Valid \\
\hline & P8 & 0,1 & 0,1671 & Tidak valid \\
\hline
\end{tabular}

Di bawah ini output uji validitas bantuan SPSS V.26 terhadap minat beli ulang sebagai variabel Y. Sesuai dengan ketentuan yang sudah dijelaskan Metodologi Penelitian mengenai syarat suatu variable dikatakan valid yaitu nilai $\mathrm{r}$ hitung $>\mathrm{r}$ tabel maka dikatakan valid. Jadi jika dibandingkan dengan tabel 2 dengan ketentuan tersebut maka variable $\mathrm{X}$ (Harga) pernyataan 1-7 dikatakan valid dan dapat digunakan dalam kuesioner. Sedangkan pernyataan 8 tidak valid dan tidak dapat dipergunakan untuk melanjutkan penelitian. 
Tabel 3. Uji Validitas Minat Beli Ulang

\begin{tabular}{|c|c|c|c|c|}
\hline Variabel & Pernyataan & r-hitung & rtabel & Keterangan \\
\hline \multirow{6}{*}{$\begin{array}{l}\text { Minat Beli } \\
\text { Ulang (Y) }\end{array}$} & P1 & 0,828 & 0,1671 & Valid \\
\hline & P2 & 0,891 & 0,1671 & Valid \\
\hline & P3 & 0,880 & 0,1671 & Valid \\
\hline & P4 & 0,915 & 0,1671 & Valid \\
\hline & P5 & 0,818 & 0,1671 & Valid \\
\hline & P6 & 0,1 & 0,1671 & Tidak Valid \\
\hline
\end{tabular}

Sesuai dengan ketentuan yang sudah dijelaskan di Metedelogi Penelitian mengenai syarat suatu variable dikatakan valid yaitu nilai $\mathrm{r}$ hitung $>\mathrm{r}$ tabel maka dikatakan valid. Jadi jika dibandingkan dengan tabel 3 dengan ketentuan tersebut maka variable Y (Minat Beli Ulang) pernyataan 1-5 dikatakan valid dan dapat dilanjutkan ketahap berikutnya.

\section{Uji Reliabilitas}

Berikut adalah hasil uji reliabilitas yang menggunakan metode rumus Cronbach Alpa dengan pengolahan data menggunakan SPSS V.26 untuk variable X (Harga) adalah sebagai berikut :

Tabel 4. Hasil Uji Reliabilitas X Harga Reliability Statistics

\begin{tabular}{r|rr} 
Cronbach's Alpha & N of Items & \\
\hline, 941 & & 7
\end{tabular}

Sumber : data yang diolah penulis Mengunakan SPSS V.26, 2021
Sesuai ketentuan yang sudah dijelaskan Metedologi Penelitian mengenai dasar pengambilan keputusan suatu data dikatakan andal atau Reliabel jika menggunakan rumus Cronbach's Alpha yaitu > 0,6. Jadi jika dibandingkan dengan tabel 4 maka hasil uji reliabilitas variable $\mathrm{Y}$ (Harga) dengan seluruh item yang diajukan memiliki rata rata $0,975>0,6$ dan dikatakan andal atau reliabel

Berikut adalah output uji reliabilatas menggunakan rumus Cronbach's Alpha dari SPSS V.26 untuk variable Y.

\section{Tabel 5. Hasil Uji Reliabilitas Variabel Y Minat Beli ulang}

Reliability Statistics

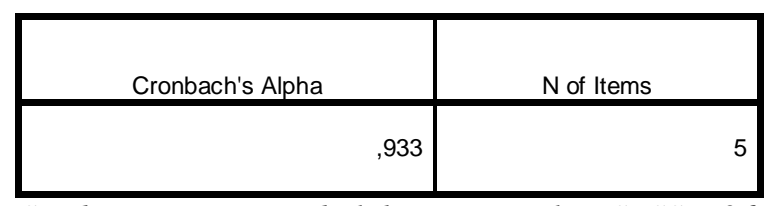

Sumber : Data yang diolah menggunakan SPSS V.26, 2021

Dasar pengambilan keputusan suatu data dikatakan andal atau Reliabel jika menggunakan rumus Cronbach's Alpha yaitu >0,6. Jadi jika dibandingkan dengan tabel 5 maka hasil uji reliabilitas variable $\mathrm{Y}$ (minat beli ulang) dengan seluruh item yang diajukan memiliki rata rata 0,933>0,6 dan dikatakan andal atau reliabel 


\section{Koefisien Determinasi}

Koefisien Determinasi $\left(\mathrm{r}^{2}\right)$ bertujuan melakukan pengukuran kemampuan variabel bebas dalam mempengaruhi variabel terikat. Berikut peneliti sajikan nilai koefisiensi korelasi yang di olah menggunakan SPSS V.26.

Tabel 6. koefisien Determinasi

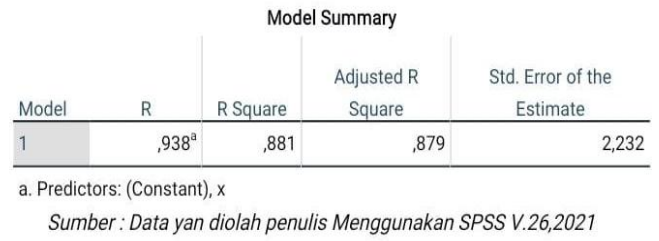

Berdasarkan tabel output SPSS tersebut, skor R Square 0,881 (81\%), yang berarti minat beli ulang di Toko Mingka Bandung $88 \%$ dipengaruhi harga dan 12\% sisanya dipengaruhi variabel luar penelitian.

\section{Uji Hipotesis (t)}

Berikut output uji t dengan bantuan SPSS V.26.

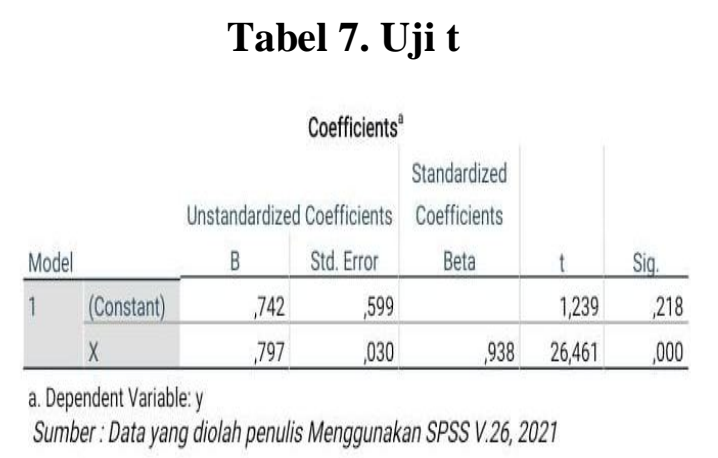

Atas output SPSS V.26 dapat disimpulkan bahwa nilai thitung adalah sebesar thitung adalah sebesar 41,994>t tabel 1,660 dan level sig. $0,00<0,05$, sehingga hipotesis pertama diterima sehingga variabel $\mathrm{X}$ (harga) berpengaruh posiitif signifikan

\subsection{Pembahasan Penelitian}

Dari hasil yang penulis peroleh dapat disimpulkan bahwa variabel X (harga) berpengaruh posiitif signifikan terhadap minat beli ulang aksesoris pakaian di Toko Mingka Bandung. Hasil studi ini sejalan dengan hasil peneliti lain yang ada kesesuaian judul dengan penulis teliti yaitu Kustianti (2019); Winata (2020) dan Wahyudi, dkk (2020) yang menghasilkan kesimpulan penelitian adanya pengaruh harga terhadap keputusan pembelian ulang, karena harga merupakan variabel inti pada pemasaran, dimana dengan berbagai alasan harga mampu mempengaruhi pembeli dalam mengambil keputusan pembelian suatu produk. Harga yang lebih murah dari kompetitor merupakan salah satu pemicu yang dapat mempengaruhi keputusan pembelian ulang dari pribadi pembeli.

Menurut Kotler \& Amstrong (2008), harga ialah total uang yang dipertukarkan atas suatu produk, harga merupakan total nilai yang dipertukarkan oleh konsumen sebanding manfaat dari 
penggunaan suatu produk. Harga ialah aspek yang dipertimbangkan konsumen ketika membeli produk dengan melakukan identifikasi harga serta nilai yang didapat.

\section{Simpulan dan Saran}

\subsection{Simpulan}

Dari hasil studi yang telah dijabarkan dengan tujuan studi untuk mengetahui bagaimana pengaruh harga atas minat pembelian uang, diperoleh kesimpulan di bawah ini.

1. Harga berpengaruh posiitif signifikan terhadap minat beli ulang aksesoris pakaian di Toko Mingka Bandung.

2. Besaran pengaruh Harga terhadap Minat beli ulang berdasarkan hitungan $\mathrm{R}$ Square $0,881(81 \%)$, berarti minatbeli ulang di toko mingka bandung mampu di pengaruhi oleh harga yang di berikan mencapai $88,1 \%, \quad 12 \%$ sisanya dipengaruhi oleh variabel di luar penelitian. terhadap variable $\mathrm{Y}$ yakni minat pembelian ulang

\subsection{Saran}

1. Untuk meningkatkan penjualan maka Toko Mingka Bandung harus mempertahankan keterjangkuan harga untuk semua kalangan.
2. Meningkatkan kualitas produk dan keragaman produk

3. Meningkatkan kuantitas produk

\section{Daftar Pustaka}

Arikunto, S.2019. Prosedur penelitian. Jakarta:Rineka Cipta

Djarwanto.1994.Pokok-pokok metode riset dan bimbingan teknis penulisan skripsi.Yogyakarta: liberty

Ghozali imam.2017. Aplikasi analisi Multivariate dengan program (IBM SPSS). Edisi 8. Badan Penerbit Universitas diponegoro. Semarang

Hayati, Rina. 2020. Pengertian kerangka berpikir menurut para ahli. https://penelitianilmiah.com/pengerti an-kerangka-berpikir-menurut-paraahli/

Korowa, E., Sumayku, S., \& Asaloei, S. (2018). "Pengaruh Kelengkapan Produk dan Harga terhadap Pembelian Ulang Konsumen". Jurnal Administrasi Bisnis, 6(3), 27-34. https://ejournal.unsrat.ac.id

Kotler, Philip \& Gary, Amstrong. 2008. Prinsip-Prinsip Pemasaran. Jilid 1 (Terjemahan: Bob Saban) Edisi Keduabelas: Jakarta: Erlangga

Kotler, Philip dan Keller L kelvin. 2009. Manajemen Pemasaran edisi ke 12. Jilid Terjemahan: Benyamin Malon PT Indeks kelompok. Jakarta: Gramedia

Kustianti, Dwi Desy Ninik.2019. Pengaruh Citra Merek dan Harga Terhadap Keputusan Pembelian Ulang Kartu 
Seluler Telkomsel. Jurnal ilmiah Psikologi (Psikoborneo) Vol 7, No 1, 2019:83-92 E-ISSN: 2477-2674.

Resti, D. (2016). "Pengaruh Persepsi Harga, Kualitas Pelayanan melalui Kepuasan Pelanggan terhadap Minat Beli Ulang pada Rumah Kecantikan Sifra Di Pati". Diponegoro Journal of Management, 5(1), 1-12. https://ejournal3.undip.ac.id

Simamora, Bilson. 2004. Panduan Riset Perilaku Konsumen. Jakarta: PT Gramedia

Sugiyono. (2013). Metode Penelitian Kuantitatif Kualitatif dan $R \& D$. Alfabeta. Pustaka Ilmu.

Thabroni, Gamal.2021.Metode Penelitian: Pengertian dan jenis menurut para ahli.https://serupa.id/metodepenelitian/.

Wahyudi, Yossy Heris. Kristanti, Dessi. Nurbambang, Rinto. 2020. Analisis Pengaruh Produk, Harga dan Kualitas Pelayanan Terhadap Keputusan Pembelian Ulang Pada Bakpia Endous Kediri. Jurnal riset bisnis dan ekonomi. Vol 1, No 1 (2020) halaman 47-67 ISSN (Online) : 2722-3361

Winata, Edi.2020. Pengaruh Kualitas Produk, Harga Dan Citra Merek terhadap Keputusan Pembelian Ulang Pulsa pada Kartu Simpati Telkomsel (Studi kasus pada mahasiswa STIM Sukma Medan). Jurnal Ilman: Jurnal Ilmu Manajemen. Volume 8, Issue 2, September 2020, pages25-32 p-
ISSN 2355-1488, e-ISSN 26152932

Zaelani, F. (2019). "Pengaruh Kualitas Produk Dan Harga Terhadap Keputusan Pembelian Fashion Muslim Online (Survey Pada Mahasiswa Fakultas Agama Islam Universitas Siliwangi)". Sarjana Tesis, Universitas Siliwangi, 148, 148-162. 